\title{
ARTIKEL PENELITIAN \\ PENGARUH KEPEMIMPINAN SENIOR, TATA KELOLA DAN TANGGUNG JAWAB SOSIAL TERHADAP KINERJA KEPALA RUANG RAWAT INAP RUMAH SAKIT KARYA BHAKTI KOTA BOGOR TAHUN 2008
}

\author{
Adila Kasni Astiena ${ }^{1}$, Hafizurrachman ${ }^{2}$, Mieke Savitri ${ }^{2}$ \\ 1. Program Studi Ilmu Kesehatan Masyarakat, Fakultas Kedokteran \\ Universitas Andalas \\ 2. Fakultas Kesehatan Masyarakat FKM-Universitas Indonesia \\ E-mail: adila.kasni@yahoo.com
}

\begin{abstract}
Abstrak
Penelitian ini bertujuan untuk mengetahui pengaruh Kepemimpinan Senior, Tata Kelola dan Tanggung Jawab Sosial Terhadap Kinerja Kepala Ruang Rawat Inap Rumah Sakit Karya Bhakti (RSKB) Bogor Tahun 2008. Kerangka teori dari penelitian ini diambil dari Malcolm Baldrige Criteria for Performance Excellence (MBCfPE) bagi institusi kesehatan dalam Hertz (2008). Kriteria $M B C f P E$ yang diambil adalah kepemimpinan (leadership) yang dijabarkan menjadi variabel Kepemimpinan Senior, Tata Kelola Dan Tanggung Jawab Sosial. Penelitian ini merupakan penelitian survei dengan pendekatan kuantitatif. Data yang dikumpulkan adalah data primer dengan menggunakan kuesioner dan diolah dengan menggunakan metode analisis jalur (Path Analysis). Responden penelitian ini adalah semua perawat ruang rawat inap Dahlia Anyelir RSKB tahun 2008. Hasil penelitian ditemukan bahwa Kepemimpinan Senior, Tata Kelola dan Tanggung Jawab Sosial mempengaruhi Kinerja Kepala Ruang sebesar 57.59\% sedangkan sisanya $42.41 \%$ dipengaruhi oleh variabel yang tidak diteliti. Variabel yang paling besar mempengaruhi kinerja kepala ruang adalah kepemimpinan senior $(30.44 \%)$ disusul oleh variabel tata kelola $(22.96 \%)$ dan Tanggung Jawab Sosial $(4.18 \%)$. Tanggung Jawab Sosial mempunyai koefisen jalur yang tidak bermakna dan sangat kecil, namun tetap dipertahankan dalam model akhir karena secara substantif, penting dalam menentukan kinerja kepala ruang. Berdasarkan penelitian ini disarankan untuk lebih memperhatikan dan meningkatkan kepemimpinan senior, tata kelola dan tanggung jawab sosial guna meningkatkan kinerja kepala ruang dengan cara (1) melakukan pembinaan dalam hal kepemimpinan mencakup kemampuan (ability), keterampilan (skill) dan perilaku (behaviour). (2) Menciptakan kebijakan guna terciptanya kondisi peningkatan kemampuan kepemimpinan senior, tata kelola dan tanggung jawab sosial, termasuk memberikan kesempatan untuk menambah pengetahuan (3) Dalam pemilihan kepala ruang disarankan untuk memperhatikan kapasitas kepemimpinan
\end{abstract}


(kemampuan, keterampilan dan tingkah laku), tata kelola dan tanggung jawab sosial dari calon kepala ruang.

Kata Kunci : Kepemimpinan Senior, Tata Kelola, Tanggung Jawab Sosial, Kinerja, Perawat

\section{Abstract}

This study has an objective to know the influence of senior leadership, governance, social responsibility to performance of roomcare head nurses in Karya Bhakti hospital Kota Bogor (RSKB) 2008. Theoretically, this concept is taken from Malcolm Baldrige Criteria for Performance Excellence (MBCfPE), in Health Care (Hertz, 2008). The choosen criteria MBCfPE is Leadership. Leadership criteria consist of senior leadership, governance and social responsibility variables. The study design is a survey design with quantitative approaches. The method being used in this study is path-analysis-method. The data are primer taken by the questionaires. Respondance are taken among nurses at Dahlia Anyelir roomcare RSKB Bogor 2008. The result shows that senior leadership, governance and social responsibility influenced performance of roomcare head nurses is $57.59 \%$ while the rest $42.41 \%$ is influenced by other factors which is not included in this study. The biggest variable which influenced work performance roomcare head nurses is senior leadership (30.44\%), followed by governance $(22.96 \%)$ and social responsibility (4.18\%). Social responsibility variable is not significant to work performance roomcare head nurses, but it being defended because of substantive importance to influence work performance of roomcare headnurse. According to the result of this study, it is recommended to give more attention to improve senior leadership, governance and social responsibility to improve work performance of roomcare head nurses, such as: (1) To maintance ability, skill and behaviour of roomcare headnurses (2) To create regulation to support improvement senior leadership capacity, governance and social responsibility with opportunity to improve knowledge (3) To give suggestion for election roomcare head nurses must have leadership capacity (ability, skill and behaviour), governance and social responsibility from the candidate.

Key word : senior leadership, governance, social responsibility, work performance, nurse 


\section{Pendahuluan}

Dalam lingkungan persaingan yang semakin tajam dan bersifat global, perusahaan dituntut untuk meningkatkan mutu produk barang dan jasa yang dihasilkan. Persaingan global memberikan banyak pilihan kepada konsumen yang semakin sadar nilai dan sadar biaya untuk mengharapkan pelayanan atau jasa yang berkualitas tinggi. Kegagalan perusahaan dalam menghasilkan produk berkualitas tinggi akan menyebabkan biaya tinggi, antara lain tidak sebandingnya biaya yang dikeluarkan (output) dengan pemasukan (input) karena ditinggalkan pelanggan untuk mencari produk pesaing yang lebih berkualitas dengan harga terjangkau. ${ }^{(1)}$

Dalam mencapai kualitas tinggi perlu upaya perbaikan terus menerus. Kualitas yang tinggi menjadi tujuan semua perusahaan karena meningkatkan kepuasan pelanggan, menurunkan biaya, serta mendorong dan mempertahankan profitabilitas jangka panjang. ${ }^{(1)}$ Bagaimanapun, kepemimpinan sangat berperan untuk meningkatkan kinerja dalam menciptakan produk barang dan jasa berkualitas.

Gagalnya rumah sakit dalam melaksanakan kegiatan untuk memenuhi harapan pelanggan, baik secara langsung maupun tidak langsung pada dasarnya disebabkan oleh minimnya kemampuan manajemen guna memecahkan persoalan yang terdapat dalam sebuah organisasi. ${ }^{(2)}$ Guna mencapai sumber daya manusia yang berkinerja tinggi dibutuhkan efektivitas fungsi manajemen. Membicarakan manajemen berarti membicarakan kepemimpinan, sebab pada dasarnya inti dari manajemen adalah kepemimpinan. Kepemimpinan dan manajemen adalah ibarat dua sisi mata uang yang tidak dapat dipisahkan. Manakala pemimpin memiliki kemampuan manajerial yang baik kegiatan manajemen rumah sakit untuk mencapai tujuan organisasi yang berkinerja tinggi akan dapat dilakukan secara efektif. ${ }^{(3)}$

Sebagian besar fungsi pelayanan kepada pasien diperankan oleh perawat. Pasien yang datang ke rumah sakit tidak hanya mengharapkan kesembuhan, tetapi juga keamanan, keselamatan (safety), kenyamanan serta kepuasan. Masyarakat menilai rumah sakit tidak hanya dari aspek pemberian pelayanan oleh dokter saja, tetapi mencakup semua aspek pelayanan termasuk pelayanan keperawatan dan pelayanan penunjang lainnya yang sangat terkait dengan dimensi mutu. Dibutuhkan profesionalitas perawat untuk mencapai mutu pelayanan asuhan pasien.

Salah satu alat ukur yang digunakan untuk menilai kinerja organisasi berdasarkan pada kriteria proses adalah berdasarkan Malcolm Baldrige for Performance Excellence (MbfPE) yang di Amerika Serikat sudah dijadikan ajang penghargaan bergengsi dalam bentuk Malcolm Baldrige National Quality Award (MBQNA). Awalnya MBNQA dimaksudkan sebagai langkah-langkah untuk mencapai kinerja tinggi perusahaan bisnis manufacturing pada tahun 1987 di Amerika. Namun sejak tahun 1999 telah dikembangkan MBQNA untuk mencapai kinerja tinggi di institusi layanan kesehatan. Kriteria ini dimaksudkan untuk membantu institusi layanan kesehatan dalam menggunakan pendekatan terintegrasi terhadap manajemen penampilan organisasi yang akan berdampak bagi peningkatan kinerja rumah sakit, termasuk peningkatan kinerja pelayanan pasien. ${ }^{(4-7)}$

Kriteria MBQNA terdiri atas sekumpulan pertanyaan yang dikelompokkan menjadi 7 kriteria untuk menilai kinerja organisasi layanan kesehatan yang berfokus pada; 1) kepemimpinan, 
Adila Kasni Astiena, Hafizurrachman, Mieke Savitri PENGARUH 150 KEPEMIMPINAN SENIOR, TATA KELOLA DAN TANGGUNG JAWAB SOSIAL TERHADAP KINERJA KEPALA RUANG RAWAT INAP RUMAH SAKIT KARYA BHAKTI KOTA BOGOR TAHUN 2008

2) perencanaan strategik, 3) fokus pada pasien, pelanggan lainnya dan market, 4) pengukuran, analisis dan pengetahuan manajemen, 5) fokus pada karyawan, 6) manajemen proses, dan 7) hasil. ${ }^{(4)}$ Kriteria kepemimpinan (leadership), menilai proses kepemimpinan pada sebuah organisasi layanan kesehatan yang mencakup 3 aspek penilaian yaitu; 1). bagaimana pemimpin senior menjalankan roda kepemimpinan organisasi, 2) bagaimana tata kelola organisasi, dan 3) bagaimana tanggung jawab sosial organisasi terhadap masyarakat termasuk perilaku sesuai hukum dan etika dalam hubungannya dengan peningkatan kinerja organisasi layanan kesehatan. ${ }^{(4)}$

Perawat adalah komponen sumber daya manusia (SDM) dengan jumlah terbanyak (hampir 50\%) di Rumah Sakit Karya Bhakti. ${ }^{(8)}$ Perawat Kepala ruang mempunyai peranan yang strategis untuk meningkatkan kinerja pelayanan khususnya, dan rumah sakit umumnya, karena berhubungan langsung dengan perawat pelaksana dalam memberikan pelayanan keperawatan kepada pasien. Diperlukan eksekutif perawat yang tidak hanya berfungsi sebagai manajer, tapi juga sebagai pemimpin dalam manajemen keperawatan ruangan yang berfungsi memberikan pelayanan berorientasi mutu. Makin bertambahnya jumlah pesaing menyebabkan RS Karya Bhakti semakin memperhatikan mutu pelayanan pasien yang saat ini sedang dalam tahap mendapatkan akreditasi dalam 16 bidang pelayanan. Penilaian Kepemimpinan Senior, Tata Kelola dan Tanggung Jawab Sosial dihubungkan dengan Kinerja Kepala Ruang Rawat Inap yang berorientasi proses dengan Kriteria dari Malcolm Baldrige (Malcolm Baldrige Criteria for Performance Excellence) belum pernah dilakukan di RS Karya
Bhakti. Perlu dilakukan penilaian kepemimpinan senior, tata kelola dan tanggung jawab sosial dihubungkan dengan kinerja kepala ruang sesuai dengan Kriteria Malcolm Baldrige.

\section{METODE PENELITIAN}

Desain penelitian yang digunakan adalah survei dengan pendekatan kuantitatif. Pada penelitian ini digunakan analisis jalur untuk menjelaskan hubungan kausal dan menguji hipotesis. Menurut Rutherford (1993) analisis jalur adalah teknik untuk menganalisis hubungan sebab akibat yang terjadi pada regresi linear berganda, jika variabel bebasnya mempengaruhi variabel tergantung, baik secara langsung maupun tidak langsung. ${ }^{(9)}$ Menurut Webley (1997), analisis jalur merupakan pengembangan langsung dari regresi berganda dengan tujuan untuk mengestimasi tingkat kepentingan (magnitude) dan signifikansi (significance) hubungan sebab akibat hipotetikal dalam seperangkat variabel. ${ }^{(8)}$ Path analysis digunakan apabila secara teori kita yakin berhadapan dengan masalah yang berhubungan sebab akibat. Oleh karena itu, sebelum melakukan analisis jalur variabelvariabel yang diteliti digambarkan dalam sebuah model. Seperangkat variabel yang diuji tersebut pada penelitian ini adalah; Kepemimpinan Senior $\left(\mathrm{X}_{1}\right)$, Tata Kelola $\left(\mathrm{X}_{2}\right)$, Tanggung Jawab Sosial $\left(\mathrm{X}_{3}\right)$ dan Kinerja Kepala Ruang (Y).

Tempat penelitian dilakukan di Rumah Sakit Karya Bhakti (RSKB) Kota Bogor. Penelitian ini dilaksanakan pada Bulan Desember 2008. Responden pada penelitian ini adalah semua perawat ruang rawat inap yang bekerja di RSKB Ruang Dahlia Anyelir. Berdasarkan data kepegawaian pada November 2008 diketahui jumlah 
perawat rawat inap Dahlia Anyelir KB berjumlah sebanyak 30 orang.

\section{HASIL PENELITIAN}

Hasil penelitian menunjukkan bahwa 90\% responden (27 orang) adalah wanita. Umur responden $60 \%$ adalah 26 - 30 tahun (18 orang). Tingkat pendidikan responden terbanyak (86.7\%) adalah diploma (26 orang). Masa kerja terbanyak pada responden adalah 1-5 tahun dan $6-10$ tahun yaitu masing-masing $40 \%$ (masing-masing 12 orang).

Dari analisis univariat ini dapat dinilai bahwa data skor variabel
Kepemimpinan Senior, Tata Kelola, Tanggung Jawab Sosial dan Kinerja secara umum berdistribusi normal berdasarkan fakta terpenuhinya;

a. Nilai mean $=$ median $=$ modus.

b. Nilai Skewness dibagi Standar $\operatorname{Error}(S E) \leq 2$.

c. Nilai kurtosis $<7$ dan skewness $<2$.

d. Nilai hitung $Z$ skewness dan $Z$ kurtosis $>0.05$ pada $(\alpha)=0,05$.

Rekapitulasi hasil uji persyaratan dapat disimpulkan dengan tabel sebagai berikut ;

Tabel 1. Rekapitulasi Hasil Uji Persyaratan

\begin{tabular}{|c|c|c|c|c|c|}
\hline No & $\begin{array}{l}\text { Nama Uji } \\
\text { asumsi }\end{array}$ & $\begin{array}{l}\text { Kepemimpinan } \\
\text { Senior }\left(\mathbf{X}_{1}\right)\end{array}$ & $\begin{array}{c}\text { Tata } \\
\text { Kelola }\left(\mathbf{X}_{2}\right)\end{array}$ & $\begin{array}{l}\text { Tanggung Jwb } \\
\text { Sosial }\left(\mathbf{X}_{\mathbf{3}}\right)\end{array}$ & Keterangan \\
\hline 1. & Linearitas & Linear & Linear & Linear & $\begin{array}{l}\text { Terpenuhi } \\
\text { pada } X_{1}, \quad X_{2} \\
\text { dan } X_{3}\end{array}$ \\
\hline 2. & $\begin{array}{l}\text { Keberartian } \\
\text { Koefisien } \\
\text { regresi }\end{array}$ & $\begin{array}{l}\text { Signifikan/ } \\
\text { berarti }\end{array}$ & $\begin{array}{l}\text { Signifikan/ } \\
\text { berarti }\end{array}$ & $\begin{array}{l}\text { Signifikan/ } \\
\text { berarti }\end{array}$ & $\begin{array}{l}\text { Terpenuhi } \\
\text { pada } X_{1}, \quad X_{2} \\
\text { dan } X_{3}\end{array}$ \\
\hline 3. & $\begin{array}{l}\text { Homogenita } \\
\mathrm{s}\end{array}$ & Homogen & Homogen & Homogen & $\begin{array}{l}\text { Terpenuhi } \\
\text { pada } X_{1}, \quad X_{2} \\
\text { dan } X_{3}\end{array}$ \\
\hline 4. & $\begin{array}{l}\text { Normalitas } \\
\text { item } \\
\text { variabel }\end{array}$ & Distribusi normal & $\begin{array}{l}\text { Distribusi } \\
\text { normal }\end{array}$ & Distribusi normal & $\begin{array}{l}\text { Terpenuhi } \\
\text { pada } X_{1}, \quad X_{2} \\
\text { dan } X_{3}\end{array}$ \\
\hline 5. & $\begin{array}{l}\text { Normalitas } \\
\text { Galat }\end{array}$ & $\begin{array}{l}\text { Distribusi } \\
\text { Normal }\end{array}$ & $\begin{array}{l}\text { Distribusi tidak } \\
\text { normal }\end{array}$ & $\begin{array}{l}\text { Distribusi tidak } \\
\text { normal }\end{array}$ & $\begin{array}{lr}\text { Terpenuhi } & \mathrm{pd} \\
\left(\mathrm{X}_{1}\right), & \text { Tak } \\
\text { terpenuhi } & \mathrm{pd} \\
\left(\mathrm{X}_{2} \& \mathrm{X}_{3}\right) & \end{array}$ \\
\hline 6. & Eksistensi & Ada eksistensi & Ada eksistensi & Ada eksistensi & $\begin{array}{l}\text { Terpenuhi } \\
\text { pada } X_{1}, \quad X_{2} \\
\text { dan } X_{3}\end{array}$ \\
\hline 7. & Kolinearity & $\begin{array}{l}\text { Tidak terjadi } \\
\text { kolinearity }\end{array}$ & $\begin{array}{l}\text { Tidak terjadi } \\
\text { kolinearity }\end{array}$ & $\begin{array}{l}\text { Tidak terjadi } \\
\text { kolinearity }\end{array}$ & $\begin{array}{l}\text { Terpenuhi } \\
\text { pada } X_{1}, \quad X_{2} \\
\text { dan } X_{3}\end{array}$ \\
\hline
\end{tabular}

Setelah data yang diperoleh di lapangan diolah dan sudah memenuhi uji yang dipersyaratkan, maka tahapan selanjutnya dalam pengujian model kausalitas adalah melakukan analisis jalur (path analysis). Berdasarkan model kausal yang dibentuk berdasarkan teori yang dicoba dianalisis, akan diperoleh diagram analisis jalur seperti terlihat pada gambar 6.5. Setelah itu dihitung nilai koefisien korelasi dan koefisien jalur pada tiap-tiap jalur (path) yang telah dirumuskan seperti gambar berikut ; 
Adila Kasni Astiena, Hafizurrachman, Mieke Savitri PENGARUH 152 KEPEMIMPINAN SENIOR, TATA KELOLA DAN TANGGUNG JAWAB SOSIAL TERHADAP KINERJA KEPALA RUANG RAWAT INAP RUMAH SAKIT KARYA BHAKTI KOTA BOGOR TAHUN 2008

\section{Gambar 1. Model Hubungan Struktural Antar Variabel}

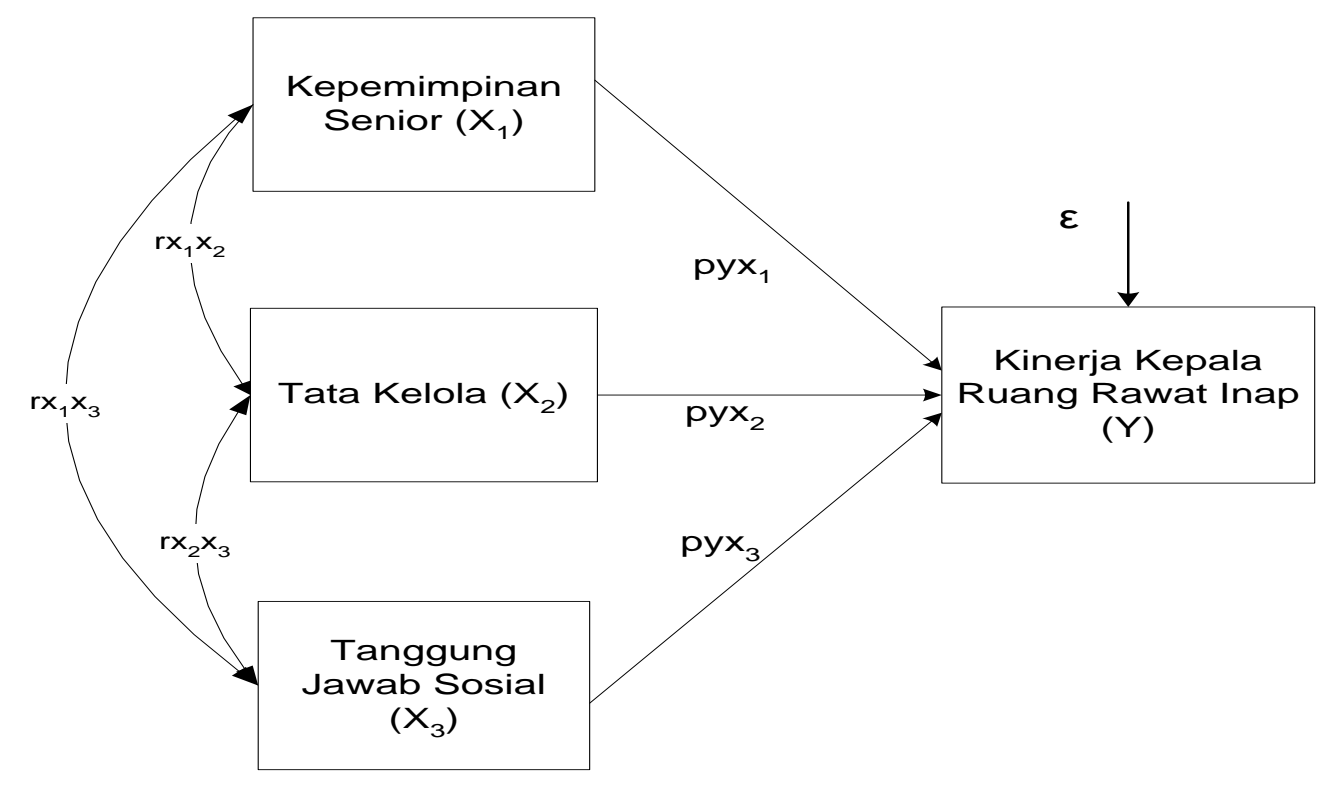

$\mathrm{Pyx}_{1}=$ koefisien jalur kinerja atas kepemimpinan senior, $\mathrm{Pyx}_{2}=$ koefidien jalur kinerja atas tata kelola, pyx $_{3}=$ koefisien jalur kinerja atas tanggung jawab sosial, $\mathrm{R}=$ koefisien residu, $\operatorname{rx}_{1} \mathrm{x}_{2}=$ korelasi antara kepemimpinan senior dengan tata kelola- $\mathrm{rx}_{2} \mathrm{x}_{3}=$ korelasi tata kelola dengan tanggung jawab sosial, $\mathrm{rx}_{1} \mathrm{x}_{3}=$ korelasi kepemimpinan senior dengan tanggung jawab sosial.

Korelasi kepemimpinan senior, tata sehingga Ho diterima, artinya jalur kelola dan tanggung jawab sosial antara Tanggung Jawab Sosial terhadap terhadap kinerja masing-masing dida- Kinerja Kepala Ruang tidak signifikan. patkan nilai 0.727, 0.707 dan 0.596. Menurut Sudjana (1996), bahwa apabila Nilai koefisien jalur antara kepemim- suatu koefisien jalur mempunyai pinan senior, tata kelola dan tanggung pengaruh yang tidak bermakna maka jawab sosial terhadap kinerja ( $\mathrm{pyx}_{1}$, secara statistik dapat dihilangkan dari $\mathrm{pyx}_{2}$, dan $\mathrm{pyx}_{3}$ ) masing masing adalah model. Selanjutnya dilakukan uji signi0.4184, 0.32473 dan 0.070. Berdasar- fikansi jalur Kepemimpinan Senior dan kan hasil perhitungan didapatkan Tata Kelola atas Kinerja Kepala Ruang pengaruh langsung antara $X_{1}, X_{2}$ dan $X_{3}$ dengan perhitungan koefisien jalur terhadap $\mathrm{Y}$ masing-masing adalah dilakukan dari awal dengan 2 jalur $0.175,0.105$ dan 0.0049. Dengan tersebut. demikian Kepemimpinan senior, Tata Kelola dan Tanggung Jawab Sosial koefisien jalur kepemimpinan senior seara bersama-sama mempengaruhi terhadap kinerja kepala ruang didapatKinerja Kepala Ruang sebesar 57.59\%, kan nilai $t_{\text {hitung }}=2.172,>t_{\text {tabel }}(=$ sedangkan $42.41 \%$ sisanya dipengaruhi 2.0518$)$ pada $(\alpha) 0.05$ dan derajat oleh variabel lain yang tidak diteliti. kepercayaan 27 (n-k-1), sehingga Ho

Dari hasil uji signifikansi ditolak, artinya jalur antara kepemimTanggung Jawab Sosial atas Kinerja pinan senior terhadap kinerja adalah Kepala Ruang didapatkan nilai $t_{\text {hitung }}=$ bermakna. Dari hasil uji signifikansi $0.365,<\mathrm{t}_{\text {tabel }}(=2.0518)$ pada $(\alpha) 0.05$ tata kelola atas kinerja kepala ruang dan derajat kepercayaan $27(\mathrm{n}-\mathrm{k}-1)$, didapatkan nilai $\mathrm{t}_{\text {hitung }}=1.654,<\mathrm{t}_{\text {tabel }}(=$ 
2.0518) pada $(\alpha) 0.05$ dan derajat terhadap kinerja kepala ruang tidak kepercayaan 27 (n-k-1), sehingga Ho signifikan.

diterima, artinya jalur antara tata kelola

Tabel 2. Rekapitulasi Hasil Pengujian Hipótesis

\begin{tabular}{|c|c|c|c|c|}
\hline No & Hipotesis & Uji Statistik & Keputusan & Kesimpulan \\
\hline 1 & 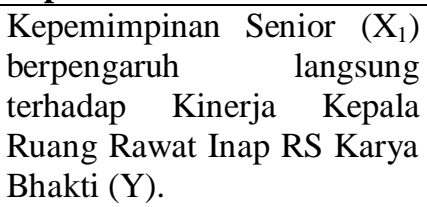 & $\begin{array}{l}\text { Ho: } \mathrm{pYX}_{1}=0 \\
\text { Ha }: \mathrm{pYX}_{1} \neq 0\end{array}$ & Ho ditolak & $\begin{array}{l}\text { Berpengaruh } \\
\text { langsung }\end{array}$ \\
\hline 2 & $\begin{array}{l}\text { Tata Kelola }\left(\mathrm{X}_{2}\right) \\
\text { berpengaruh } \\
\text { terhadap Kinerja Kepala } \\
\text { Ruang Rawat Inap RS Karya } \\
\text { Bhakti (Y). }\end{array}$ & $\begin{array}{l}\text { Ho }: \mathrm{pYX}_{2}=0 \\
\text { Ha }: \mathrm{pYX}_{2} \neq 0\end{array}$ & Ho diterima & $\begin{array}{c}\text { Tidak } \\
\text { Berpengaruh } \\
\text { langsung }\end{array}$ \\
\hline 3. & $\begin{array}{l}\text { Tanggung Jawab Sosial }\left(\mathrm{X}_{3}\right) \\
\text { berpengaruh } \quad \text { langsung } \\
\text { terhadap Kinerja Kepala } \\
\text { Ruang rawat Inap RS Karya } \\
\text { Bhakti }(\mathrm{Y})\end{array}$ & $\begin{array}{l}\text { Ho }: \mathrm{pYX}_{3}=0 \\
\text { Ha }: \mathrm{pYX}_{3} \neq 0\end{array}$ & Ho diterima & $\begin{array}{c}\text { Tidak } \\
\text { Berpengaruh } \\
\text { Langsung }\end{array}$ \\
\hline
\end{tabular}

Tabel 3. Koefisien Jalur Pengaruh Langsung dan Tidak Langsung Kepemimpinan Senior $\left(X_{1}\right)$, Tata Kelola $\left(X_{2}\right)$ dan Tanggung Jawab Sosial Terhadap Kinerja Kepala Ruang (Y)

\begin{tabular}{|c|c|c|c|c|c|}
\hline \multirow{3}{*}{ Variabel } & \multicolumn{4}{|c|}{ Pengaruh } & \multirow{3}{*}{ Total } \\
\hline & \multirow{2}{*}{ Langsung } & \multicolumn{3}{|c|}{ Tidak Langsung } & \\
\hline & & $\mathbf{X}_{1}$ & $\mathbf{X}_{2}$ & $\mathbf{X}_{3}$ & \\
\hline X1 Terhadap Y & $17.51 \%$ & None & $10.83 \%$ & $2.10 \%$ & $30.44 \%$ \\
\hline X2 Terhadap Y & $10.54 \%$ & $10.83 \%$ & None & $1.59 \%$ & $22.96 \%$ \\
\hline X3 Terhadap Y & $0.49 \%$ & $2.10 \%$ & $1.59 \%$ & None & $4.18 \%$ \\
\hline Pengaruh Bersama & \multicolumn{4}{|c|}{ Pengaruh Bersama X1,X2 dan X3 Thd $\mathrm{Y}$} & $57.59 \%$ \\
\hline Residu (e) & \multicolumn{4}{|c|}{ Pengaruh Faktor Lain Yang Tidak Diteliti } & $42.41 \%$ \\
\hline
\end{tabular}

Keterangan : $\mathrm{X}_{1}-\mathrm{Y}=$ Pengaruh Kepeminpinan Senior terhadap Kinerja, $\mathrm{X}_{2}-\mathrm{Y}=$ Pengaruh Tata Kelola terhadap Kinerja, $X_{1}=$ Kepemimpinan señor $X_{2}=$ Tata Kelola $Y=$ Kinerja

Model akhir jalur uji ditampilkan seperti gambar berikut ini ; 
Adila Kasni Astiena, Hafizurrachman, Mieke Savitri PENGARUH 154 KEPEMIMPINAN SENIOR, TATA KELOLA DAN TANGGUNG JAWAB SOSIAL TERHADAP KINERJA KEPALA RUANG RAWAT INAP RUMAH SAKIT KARYA BHAKTI KOTA BOGOR TAHUN 2008

\section{Gambar 2. Model Akhir Hubungan Struktural Antar Variabel}



Gambar 3. Persentase Faktor-Faktor Yang Mempengaruhi Kinerja Kepala Ruang RS Karya Bhakti Kota Bogor Tahun 2008

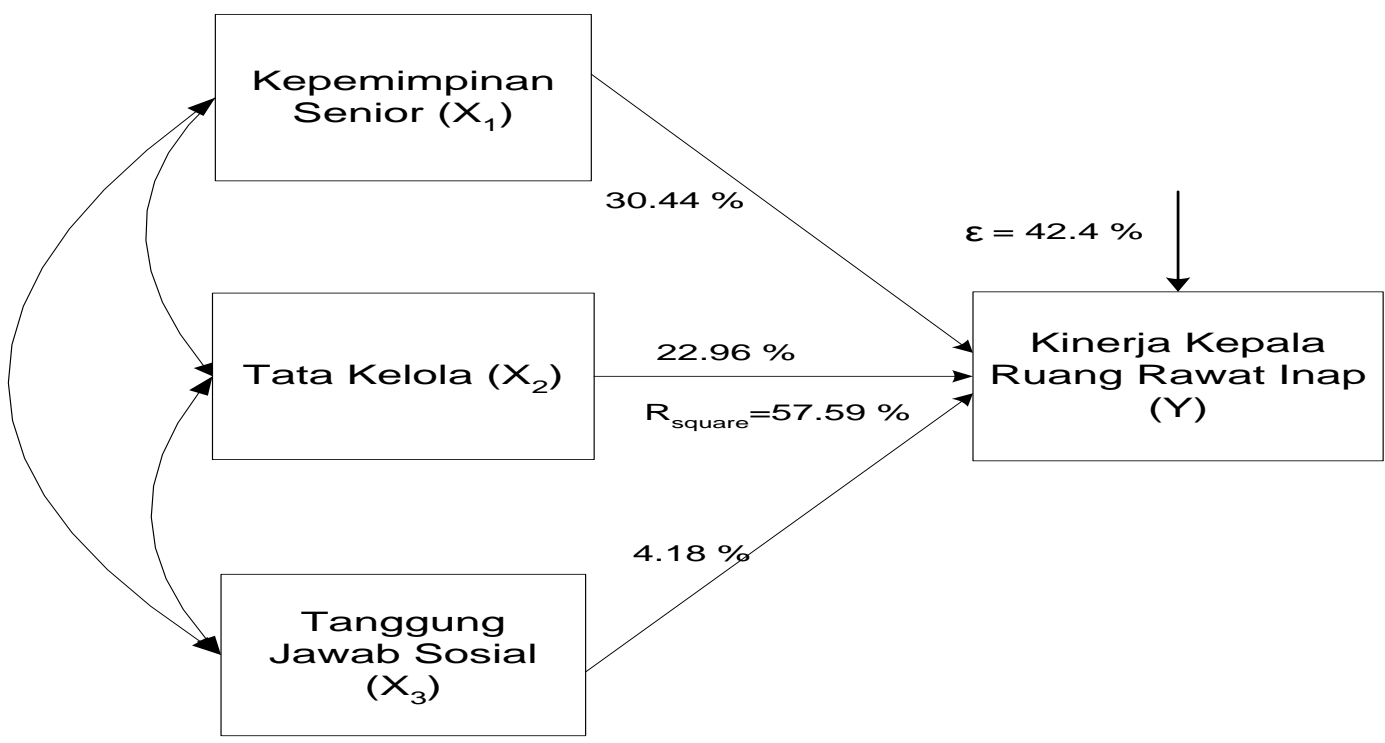

PEMBAHASAN

Dari model yang diajukan, ternyata Kepemimpinan Senior memiliki pengaruh yang paling besar dalam menen- tukan Kinerja Kepala Ruang, yakni sebesar 30.44\%. Artinya 30.44\% Kinerja Kepala Ruang dapat diprediksi berdasarkan kepemimpinan senior 
Adila Kasni Astiena, Hafizurrachman, Mieke Savitri PENGARUH 156 KEPEMIMPINAN SENIOR, TATA KELOLA DAN TANGGUNG JAWAB SOSIAL TERHADAP KINERJA KEPALA RUANG RAWAT INAP RUMAH SAKIT KARYA BHAKTI KOTA BOGOR TAHUN 2008

kepala ruang. Hal ini sesuai dengan apa pinan yang baik akan menghasilkan yang dikatakan oleh Shortell dan kinerja yang baik dari karyawan Kaluzny (2007) bahwa kepemimpinan (perawat lini atau perawat pelaksana). yang baik akan menghasilkan pengikut Mengenai peran kepemimpinan yang cerdas yang akan berdampak bagi terhadap peningkatan kinerja dimodikinerja kepemimpinan dan pada akhir- fikasi dari gambaran Yukl (2007) nya membawa dampak bagi pening- dengan skema sebagai berikut $;^{(11)}$ katan kinerja organisasi. ${ }^{(10)}$ Kepemim-

\section{Gambar 4. Skema Pengaruh Kepemimpinan Terhadap Kinerja}



Upaya peningkatan kinerja manajemen pelayanan dan keuangan, kepemimpinan ditempuh dengan transparansi dalam pengambilan kebijapeningkatan keterampilan kepemim- kan dan penglolaan ruangan serta indepinan serta perilaku kepemimpinan. penden dalam pemeriksaan (audit), Sebagai seorang manajer sekaligus profesionalisme serta kejujuran. pemimpin di ruangan perawatan, ciri, keterampilan dan perilaku kepemimpinan yang harus dimiliki seorang kepala ruang adalah berkomunikasi dengan efektif, konsistensi perilaku, melibatkan semua karyawan, memberikan motivasi dan berkomitmen terhadap hasil kerja.

Sebanyak $22.96 \%$ kinerja kepala ruangan ditentukan oleh tata kelola. Tata kelola yang baik mencakup upaya untuk menjalankan good corporate governance (tata kelola perusahaan yang baik) meliputi akuntabilitas, transparansi dan independensi. Dalam menjalankan tata kelola keperawatan yang baik, kepala ruang dituntut untuk menjalankan organisasi keperawatan sesuai dengan clinical governance meliputi meliputi akuntabilitas terhadap

Akuntabilitas terhadap manajemen pelayanan dapat ditempuh dengan menciptakan sistem pengelolaan ruangan yang baik yang menjamin pertanggung jawaban setiap tindakan manajemen yang dilakukan, pemberian informasi secara tepat waktu, memadai, jelas, akurat, ramah dan terbuka dalam proses operasional, dapat diperbandingkan serta mudah diakses oleh stakehoder (pasien, perawat pelaksana, atasan maupun direksi rumah sakit) sesuai dengan haknya. Prinsip keterbukaan informasi tidak mengu-rangi kewajiban untuk memenuhi rahasia jabatan sebagai perawat sesuai undangundang dan etika keperawatan yang berlaku, tidak melanggar hak-hak pribadi individu, terutama hak pasien sebagai penerima pelayanan. ${ }^{(12,13)}$ 
Disamping itu, tata kelola yang baik harus melakukan evaluasi kinerja pelayanan keperawatan secara berkala dan teratur, baik dilakukan oleh kepala ruangan itu sendiri, maupun oleh atasan yang lebih tinggi dengan memberikan.

Data yang jujur dan independen sesuai prinsip profesionalisme keperawatan dan fairness (kejujuran), tanpa ada yang ditutupi atau dimanipulasi. ${ }^{(13,14)}$

Tata kelola yang baik juga memastikan bahwa setiap pelayanan keperawatan yang diberikan kepada pasien sudah dilakukan antisipasi resiko atau dampak negatif pelayanan. Hal ini dapat terlaksana dengan melakukan pelayanan sesuai Standar prosedur (SOP) keperawatan yang sudah disosialisasikan sebelumnya kepada perawat pelaksana. Hal ini dilakukan bekerja sama dengan manajemen resiko dan keselamatan pasien di rumah sakit. Tata kelola keperawatan ruang berdampak pada kemampuan untuk mempertanggung-jawabkan mutu pelayanan keperawatan di ruangan secara terus menerus dengan menjaga standar pelayanan klinik yang bermutu tinggi dengan menciptakan lingkungan kerja yang kondusif. Artinya semakin baik tata kelola yang dijalankan kepala ruangan, semakin baik kinerja kepala ruang tersebut yang akan membawa dampak bagi peningkatan mutu pelayanan dan kinerja rumah sakit. Mutu asuhan keperawatan dapat dicapai bila dalam bekerja dipenuhinya standar profesi dalam pelayanan pasien, terwujudnya hasil (outcome) seperti yang diharapkan menyangkut asuhan pasien, diagnosis serta prosedur dan tindakan keperawatan. ${ }^{(14)}$

Temuan penelitian selanjutnya adalah bahwa tanggung jawab sosial mempunyai dampak langsung yang kecil dan koefisien jalur yang tidak signifikan terhadap kinerja kepala ruang, sehingga secara teori statistik dapat dikeluarkan dari model. Namun, secara substantif, tanggung jawab sosial memiliki peranan yang penting dalam mempengaruhi kinerja kepala ruang, sehingga tetap dipertahankan dalam model akhir. Meskipun hasil yang didapatkan tidak berarti apa-apa dibandingkan pengaruh kepemimpinan dan tata kelola terhadap kinerja, sebenarnya tanggung jawab sosial ini diperankan oleh perawat pelaksana yang akan berdampak terhadap mutu pelayanan yang diberikan. Tanggung jawab keperawatan meliputi upaya pemberian asuhan paripurna (biopsiko-sosial mental dan spritual) kepada pasien sebagai tugas pokok perawat, menghargai kepercayaan dan nilai-nilai dan kebiasaan pasien, mempertahankan standar asuhan keperawatan yang tinggi, memprakarsai dan mendukung berbagai kegiatan guna memenuhi hubungan masyarakat, memelihara hubungan baik dengan sesama perawat dan tenaga kesehatan lainnya, serta berpartisipasi dalam pendidikan keperawatan dan organisasi profesi. ${ }^{(12-14)}$ Bagaimanapun pemberian asuhan paripurna dan mempertahankan standar mutu pelayanan keperawatan yang yang merupakan beberapa komponen dari tanggung jawab sosial memberikan kontribusinya terhadap peningkatan kinerja kepala ruang. ${ }^{(14)}$ Dan memang sebenarnya tanggung jawab sosial lebih berperan dalam penilaian masyarakat terhadap organisasi (rumah sakit) secara

umum. Bila suatu rumah sakit memiliki tanggung jawab sosial yang besar, maka akan berdampak terhadap citra rumah sakit yang dapat menarik pelanggan. Kepercayaan yang meningkat artinya akan meningkatkan jumlah kunjungan yang bermuara pada meningkatnya kinerja rumah sakit. 
Adila Kasni Astiena, Hafizurrachman, Mieke Savitri PENGARUH 158 KEPEMIMPINAN SENIOR, TATA KELOLA DAN TANGGUNG JAWAB SOSIAL TERHADAP KINERJA KEPALA RUANG RAWAT INAP RUMAH SAKIT KARYA BHAKTI KOTA BOGOR TAHUN 2008

\section{KESIMPULAN}

Kepemimpinan Senior $\left(\mathrm{X}_{1}\right)$ berpengaruh langsung secara signifikan terhadap Kinerja Kepala Ruang (Y). Disamping itu, juga terdapat pengaruh tidak langsung Kepemimpinan Senior $\left(\mathrm{X}_{1}\right)$ terhadap Kinerja Kepala Ruang (Y) melalui Tata Kelola $\left(\mathrm{X}_{2}\right)$ dan Tanggung Jawab Sosial $\left(\mathrm{X}_{3}\right)$. Kedua, Tata Kelola $\left(\mathrm{X}_{2}\right)$ memiliki pengaruh langsung yang tidak signifikan terhadap Kinerja Kepala Ruang (Y). Prosentase pengaruh langsung Tata Kelola adalah sebesar $10.54 \%$, namun Tata Kelola memiliki pengaruh tidak langsung yang cukup tinggi terhadap Kinerja Kepala Ruang (Y), melalui Kepemimpinan senior (10.83\%) maupun melalui Tanggung Jawab Sosial (1.59\%). Ketiga, Walaupun dari hasil perhitungan statistik tidak terdapat signifikansi Tanggung Jawab Sosial $\left(\mathrm{X}_{3}\right)$ terhadap Kinerja Kepala Ruang (Y), namun tetap dipertahankan dalam model karena mempunyai pengaruh secara substantif.

Kinerja Kepala Ruang dipengaruhi sebesar $57.59 \%$ oleh Kepemimpinan Senior, Tata Kelola dan Tanggung Jawab Sosial Kepala Ruang, Bila manajemen rumah sakit melakukan pembinaan terhadap aspek Kepemimpinan, Tata Kelola dan Tanggung Jawab Sosial Kepala Ruang maka akan meningkatkan Kinerja Kepala Ruang sebesar 57.59\%. Sebanyak $42.41 \%$ Kinerja Kepala Ruang (Y) dipengaruhi oleh faktor lain yang tidak diteliti.

\section{SARAN}

Dalam upaya peningkatan kinerja kepala ruang, perlu dilakukan intervensi terhadap peningkatan kapasitas kepemimpinan kepala ruang, tata kelola dan tanggung jawab sosial kepala ruang antara lain dengan mengadakan pelatihan kepemimpinan, training peningkatan motivasi (achievement motivation training atau AMT) serta pelatihan guna meningkatkan pehamanan terhadap tata kelola keperawatan yang baik dan tanggung jawab sosial. Pembinaan dapat dilakukan melalui acara khusus seperti seminar dan pelatihan, maupun pembinaan melalui rapat, pertemuan dan laporan jaga dengan supervisor dan kepala bidang keperawatan.

Dalam pemilihan kepala ruang, hendaknya dicari kandidat dengan kapasitas kepemimpinan yang baik (ability, skill, behaviour), tata kelola (governance) serta tanggung jawab sosial (social responsibility) sebagaimana telah dijelaskan sebelumnya. Bagi kepala ruang, perlu dengan sadar meningkatkan efektivitas kepemimpinannya dengan aktif membina diri, meningkatkan motivasi diri (self motivation) sesuai perannya sebagai panutan (rule models) sehingga diharapkan membawa dampak bagi kinerja kepala ruang.

Mengingat beratnya tugas dan tanggung jawab yang diemban oleh perawat pelaksana sebagai manajer lini pelayanan keperawatan, manajemen rumah sakit hendaknya meningkatkan perhatian terhadap kepuasan kerja kepala ruang, karena bagaimanapun kepuasan kerja akan berdampak pada peningkatan kinerja kepala ruang dan kinerja perawat pelaksana dan rumah sakit pada akhirnya. Banyak variabel yang mempengaruhi kinerja kepala ruang, perlu dilakukan penelitian lanjutan guna menemukan variabel lain yang berpengaruh terhadap kinerja kepala ruang.

\section{KEPUSTAKAAN}

1. Nassar, M, 2004,
Perbandingan
Keuangan Perusahaan Yang 
bersertifikasi ISO 9000 dan ISO 14000, dari: (digilib@umm.ac.id) [tgl.26 Agustus, 2008].

2. Sabarguna, Boy, Knowledge Management untuk Rumah Sakit, Jakarta: Sagung Seto; 2007.

3. Sulistiani, Ambar Teguh, Memahami Good Governance dalam Perspektif Sumber Daya Manusia, Yogyakarta: Gaya Media; 2004.

4. Hertz, H S, Health Care Criteria for Performance Excellence, America: Baldrige National Quality Program; 2007.

5. Sadikin, Iskandar, Bunga Rampai Kriteria Malcolm Baldrige National Quality Award (MBNQA), Bogor: Lembayung Center Indonesia; 2008.

6. Sadikin, Iskandar, Self Asessment Berbasis Malcolm Baldrige National Quality Award (MBNQA), Bogor: Lembayung Center Indonesia; 2008.

7. Sadikin, Iskandar, Penuntun Menyusun Aplikasi Baldrige, Bogor: Lembayung Center Indonesia; 2008.

8. Rumah Sakit Karya Bhakti, "Profil Rumah Sakit Umum
Karya Bhakti Tahun 2007', Bogor; 2007.

9. Sarwono Jonathan, Analisis Jalur untuk Riset Bisnis dengan SPSS, Jogjakarta: Penerbit Andi; 2007.

10. Kaluzny, Arnold D., Shortell, Stephen M., Healthcare Management, Organization Design and Behavior, United States : Thomson Delmar Learning; 2006.

11. Yukl, Gary, Leadership in Organization, fith edition, alih bahasa Budi Supriyanto, Kepemimpinan dalam Organisasi, Jakarta: Penerbit PT Index; (2001).

12. Nursalam, Manajemen Keperawatan: Aplikasi dalam Praktik Keperawatan Profesional, ed 2, Jakarta: Penerbit Salemba Medika; 2007.

13. Blais, Kathleen, Koenig, Professional Nursing Practice: Concepts and Perspectives, alih bahasa: Yuningsih, Yuyun, Subekti, Nike Budhi, editor. Ariani, Fruriolina, Karyuni, Pamilih Eko, Jakarta: Penerbit Buku Kedokteran EGC; 2002.

14. Nursalam, Proses dan Dokumentasi Keperawatan, Konsep \& Praktik, Jakarta: Penerbit Salemba Medika; 2006. 